\title{
Geospatial Health: the first five years
}

\author{
Jürg Utzinger ${ }^{1,2}$, Laura Rinaldi ${ }^{3}$, John B. Malone ${ }^{4}$, Stefanie J. Krauth ${ }^{1,2}$, Thomas K. \\ Kristensen $^{5,6}$, Giuseppe Cringoli ${ }^{3}$, Robert Bergquist ${ }^{7}$ \\ ${ }^{1}$ Department of Epidemiology and Public Health, Swiss Tropical and Public Health Institute, P.O. Box, CH-4002 \\ Basel, Switzerland; ${ }^{2}$ University of Basel, P.O. Box, CH-4003 Basel, Switzerland; ${ }^{3}$ Department of Pathology and \\ Animal Health, Faculty of Veterinary Medicine, University of Naples Federico II, Naples, Italy; ${ }^{4}$ Department of \\ Pathobiological Sciences, School of Veterinary Medicine, Skip Bertman Drive, Louisiana State University, Baton \\ Ronge, LA, USA; ${ }^{5}$ DBL, Department of Veterinary Disease Biology, University of Copenhagen, Thorvaldsensvej \\ 57, DK-1871 Frederiksberg C, Denmark; ${ }^{6}$ School of Biological \& Conservation Sciences, Faculty of Science and \\ Agriculture, University of KwaZulu-Natal, South Africa; ${ }^{7}$ Ingerod, Brastad, Sweden
}

\begin{abstract}
Geospatial Health is an international, peer-reviewed scientific journal produced by the Global Network for Geospatial Health (GnosisGIS). This network was founded in 2000 and the inaugural issue of its official journal was published in November 2006 with the aim to cover all aspects of geographical information system (GIS) applications, remote sensing and other spatial analytic tools focusing on human and veterinary health. The University of Naples Federico II is the publisher, producing two issues per year, both as hard copy and an open-access online version. The journal is referenced in major databases, including CABI, ISI Web of Knowledge and PubMed. In 2008, it was assigned its first impact factor (1.47), which has now reached 1.71. Geospatial Health is managed by an editor-in-chief and two associate editors, supported by five regional editors and a 23-member strong editorial board. This overview takes stock of the first five years of publishing: 133 contributions have been published so far, primarily original research $(79.7 \%)$, followed by reviews $(7.5 \%)$, announcements $(6.0 \%)$, editorials and meeting reports $(3.0 \%$ each) and a preface in the first issue. A content analysis of all the original research articles and reviews reveals that three quarters of the publications focus on human health with the remainder dealing with veterinary health. Two thirds of the papers come from Africa, Asia and Europe with similar numbers of contributions from each continent. Studies of more than 35 different diseases, injuries and risk factors have been presented. Malaria and schistosomiasis were identified as the two most important diseases $(11.2 \%$ each). Almost half the contributions were based on GIS, one third on spatial analysis, often using advanced Bayesian geostatistics (13.8\%), and one quarter on remote sensing. The 120 original research articles, reviews and editorials were produced by 505 authors based at institutions and universities in 52 countries. Importantly, a considerable proportion of the authors come from countries with a low or medium human development index $(29.3 \%)$. In view of the increasing number of submissions, we are considering to publish more than two issues per year in the future. Finally, our vision is to open-up a new section predominantly based on visual presentations, including brief video clips, as discussed in a symposium at the $60^{\text {th }}$ annual meeting of the American Society of Tropical Medicine and Hygiene in December 2011.
\end{abstract}

Keywords: bibliometric analysis, content analysis, geographical information system, Geospatial Health, human development index, remote sensing, spatial analysis, visualization.

\section{Introduction}

Ever since Snow's map rendition of the risk for cholera in London (Snow, 1855), geographical reconnaissance, mapping of disease occurrence and risk stratification have played important roles in the prevention and control of human and animal disease. For example, mapping the distribution of hookworm in Texas more than 100 years ago (Smith, 1903) was a

\footnotetext{
Corresponding author:

Jürg Utzinger

Department of Epidemiology and Public Health

Swiss Tropical and Public Health Institute

P.O. Box CH-4002 Basel, Switzerland

Tel. +41 61 284-8129; Fax +41 61 284-8105

E-mail: juerg.utzinger@unibas.ch
}

crucial step to forge control efforts, which eventually led to the elimination of hookworm disease in the United States (Stiles, 1939). Risk mapping of malaria at small spatial scales was a key feature to guide multifaceted control approaches in Africa, Asia and the Americas shortly after the life cycle of this disease was fully elucidated (Watson, 1921, 1953; Maxcy, 1923).

The advent of aerial photography followed by Earth-observing satellites equipped with sensitive remote-sensing instruments opened up new opportunities for epidemiology and public health as foreseen by Cline when he was still a student (Cline, 1970). Since then, powerful satellite-based remote sensing and computer-based geographical information system (GIS), including advanced geostatistical analyses, have made great strives to further our understanding of the 
epidemiology and control of human and veterinary diseases at different spatial and temporal scales. Indeed, reviews in leading medical journals have emphasized the strong potential of geospatial tools for health applications (Brooker and Michael, 2000; Hay et al., 2000; Brooker, 2002; Kistemann et al., 2002; Tanser and le Sueur, 2002; Cromley, 2003; Ceccato et al., 2005; Yang et al., 2005; Simoonga et al., 2009; Bergquist and Rinaldi, 2010; Bergquist, 2011; Khan et al., 2011). Additionally, special issues have been published in Advances in Parasitology (in 2000), Acta Tropica (in 2001) and Parassitologia (in 2005), discussing how the integration of GIS, remote sensing and spatial analysis can contribute to the establishment of early warning systems (EWS), risk mapping and prediction of epidemics due to diseases that are of major importance, both for public health and veterinary medicine. Moreover, two specialized journals are now available that are fully dedicated to all aspects of geospatial techniques for applications in health and healthcare, namely the International Journal of Health Geographics (published by BioMed Central since August 2002) and Geospatial Health (published by University of Naples for GnosisGIS since November 2006).

Here, we review the first five years of publication activities of Geospatial Health. Our overview begins with a historic account of the initial ideas and formation of the GnosisGIS network that was founded in 2000, and we then discuss briefly its main activities and evolution. The centre-piece of our review is an indepth analysis of the 133 contributions published in the first 10 issues (November 2006-May 2011), including type of publication, authorship, authors' country, thematic and geographic focus of the research covered, and identification of the geospatial tool(s) employed. We conclude with the editors' vision of the journal's future, including a new "visualization" section based on animations and brief video clips, as discussed at this year's annual conference of the American Society of Tropical Medicine and Hygiene in Philadelphia.

\section{GnosisGIS: once and forever}

\section{Team residency in Bellagio}

GnosisGIS is the acronym for "GIS Network $\underline{\text { On }}$ Snail-borne Infections with special reference to Schistosomiasis" (emphasis added; http://www. GnosisGIS.org). The creation of this network took place at a team residency, held at the Bellagio Study and Conference Centre in Italy on April 10-14, 2000
(Bergquist et al., 2000; Malone et al., 2001). Sponsored by the Rockefeller Foundation, it brought together 10 scientists and human and veterinary health researchers from different institutions, universities and international organization:

- Mara E. Bavia (Federal University of Bahia; Salvador, Brazil);

- Robert Bergquist (then at the UNICEF/UNDP/ World Bank/WHO Special Programme for Research \& Training in Tropical Diseases (TDR); Geneva, Switzerland);

- Michele Bernardi (Food and Agriculture Organization; Rome, Italy);

- Mohamed M. El Bahy (Cairo University; Giza, Egypt);

- Màrius V. Fuentes (University of Valencia; Valencia, Spain);

- Oscar K. Huh (Louisiana State University; Baton Rouge, United States);

- Thomas K. Kristensen (DBL, University of Copenhagen; Copenhagen, Denmark);

- John B. Malone (Louisiana State University; Baton Rouge, United States);

- Jennifer C. McCarroll (Louisiana State University; Baton Rouge, United States); and

- Xiao-Nong Zhou (National Institute of Parasitic Diseases, Chinese Center for Disease Control and Prevention; Shanghai, People's Republic of China (P.R. China)).

The goal of this team residency was to develop and consolidate a network of collaborators dedicated to the development, validation and use of global computerbased models who had been informally discussing how to enhance the effectiveness of control programmes for schistosomiasis and other snail-borne diseases of medical and veterinary importance. The impetus came from previous successful applications of an integrated approach using GIS, remote sensing and spatial analysis to map the distribution of schistosomiasis and fascioliasis in different parts of the world (Cross and Bailey, 1984; Cross et al., 1984; Malone et al., 1992, 1994, 1998). Progress had already been made with these techniques for EWS, risk profiling of malaria, human African trypanosomiasis and other tropical diseases (Beck et al., 1994; Hay et al., 1996; Rogers et al., 1996).

The outcome of the Bellagio meeting was the agreement on a strategic plan and organizational structure to guide future development of a new scientific group devoted to GIS, remote sensing and spatial statistics. Expected outcomes were models based on datasets of the global climate, satellite sensors, disease prevalence rates, the distribution and abundance of snail interme- 
diate hosts with the overarching aim of producing digital maps of key environmental factors that affect the development and propagation of snail-borne infectious agents. The Internet was chosen as the modus operan$d i$ for collaboration, data sharing and development of effective GIS models. It was envisaged that current and prospective disease investigations would be systematically and accurately placed in a broad geographical and ecological context using geospatial techniques.

\section{The initial years}

Work continued on the strategic plan outlined at Bellagio, and a special issue of Acta Tropica entitled "A global network on schistosomiasis information systems and control of snail-borne diseases" was published in 2001 that mainly included member research projects. A website was developed to foster communication and joint work on the specific objectives previously agreed by the group.

In the next four years, GIS resource datasets based on identified needs for current member research projects were produced in the form of minimum medical databases for the IGAD-Nile Region of Africa (2001), Asia (2003), West Africa (2004) and Latin America (2005). Based on these databases, a short-course training manual entitled "Starting up a medical GIS capability: a lessons manual and CD-Rom data resource" was developed as an introductory GIS course using ArcView and ArcGIS (i.e. the commercially available software products from ESRI headquartered at Redlands, United States). The manual was designed for use as step-by-step lesson modules for individual instruction and self-study or for short courses offered in conjunction with larger meetings to promote use of geospatial health applications. Short courses were held in different venues, usually in conjunction with various international scientific meetings: (i) the $1^{\text {st }}$ meeting of the Regional Network of Asian Schistosomiasis, Wuxi, P.R. China, 2001; (ii) the 19th International Conference of the World Association for the Advancement of Veterinary Parasitology (WAAVP), New Orleans, United States, 2003; and (iii) a DBL - Health Research and Development Centre workshop, Lusaka, Zambia, 2004.

To achieve the results envisioned, however, turned out to be an uphill struggle, the lack of a sufficiently large critical mass of active scientists and regular meetings being mentioned as the main impediments. In an effort to remedy the situation, a workshop was convened in mid-2005 at the Sealodge Centre in Smögen, Sweden, to discuss and implement needed changes.

\section{Jump-start}

The goal of the Smögen workshop was to review accomplishments since the initial meeting in Bellagio and to define expanded objectives and purposes of the group, which in turn should lead to a more ambitious stage of development. While there was consensus that the original group members had assisted each other well with regard to the development of expert resource information and methods for use of GIS tools for snail-borne diseases, the need for new targets was clear. After considerable thinking, the aims of the network were expanded and consolidated as follows:

- enlarge the scope by encompassing a wider spectrum of target diseases of medical and veterinary importance;

- obtain a higher profile and impact via peerreviewed publications, including the creation of a new open-access international journal;

- offer short courses and develop regional GIS centres for the provision of geospatial-related instruction and data;

- annual or biannual working group meetings; and

- prepare joint funding proposals supported by working group members.

The acronym GnosisGIS was kept, but the network was renamed the "Global Network for Geospatial Health". An executive committee was elected, including five members, supported by regional offices in Africa, Asia, Europe, Latin America and North America. In retrospect, the outcome of the Smögen workshop was a more focused, effective organization with members tasked to accomplish specific objectives. The greatest impact in promoting the purposes of GnosisGIS proved to be the establishment of annual meetings and the initiation of Geospatial Health as the official journal of the network.

\section{Annual meetings}

The Smögen workshop explicitly recommended annual meetings to be organized by GnosisGIS, ideally in conjunction with other national or international scientific conferences. The new activities gradually started to transform GnosisGIS into a different organization and, in retrospect, it has become clear that this recommendation was useful in achieving the set objectives. The 2005 Smögen workshop was designated the $1^{\text {st }}$ annual GnosisGIS meeting, after which the group met every year as follows:

- $2^{\text {nd }}$ annual GnosisGIS meeting, convened in July 2006 in Salina, Italy with a total of 20 members 
attending. The meeting was held back-to-back with the $19^{\text {th }}$ Congress of the Italian Society of Parasitology (SOIPA), during which a symposium on geospatial health was offered by GnosisGIS.

- $3^{\text {rd }}$ annual GnosisGIS meeting held in September 2007 in Lijiang, P.R. China, attended by 90 participants from 17 countries. This meeting was jointly organized with the Regional Network on Asian Schistosomiasis and Other Helminth Zoonoses $\left(\mathrm{RNAS}^{+}\right)$. The local organizer, Prof. Xiao-Nong Zhou, opened the meeting and named it the " 1 st International Symposium on Geospatial Health". A summary report of this meeting was published in the open-access journal Parasites \& Vectors (Zhou et al., 2009).

- $2^{\text {nd }}$ International Symposium of Geospatial Health, held in December 2008 in New Orleans, United States, attended by 48 participants from 15 countries. This meeting was organized back-to-back with the $57^{\text {th }}$ annual meeting of the American Society of Tropical Medicine and Hygiene, during which a symposium was organized by GnosisGIS.

- $3^{\text {rd }}$ International Symposium of Geospatial Health with the theme "Climate change and geospatial health" was held in September 2009 in Vietri sul Mare, Italy. There were 50 participants from 15 countries. The meeting was held back-to-back with the $7^{\text {th }}$ European Congress on Tropical Medicine and International Health that took place in Verona, Italy.

- In August 2010, the $4^{\text {th }}$ International Symposium of Geospatial Health, built around the theme "A one health approach to geospatial health", was held as a satellite meeting of the $12^{\text {th }}$ International Congress of Parasitology (ICOPA) in Melbourne, Australia. There were over 30 participants from 11 countries.

- $5^{\text {th }}$ International Symposium of Geospatial Health held in September/October 2011 in Cartagena, Colombia. The theme was "Mapping and modelling neglected tropical diseases in Latin America and the Caribbean" and GnosisGIS sponsored a session on geospatial health applications at the Federation of Latin American Parasitologists meeting, held at the University of the Andes in Bogota prior to the Cartagena meeting.

\section{Geospatial Health}

\section{Why was this journal launched?}

The inaugural issue of Geospatial Health was published in November 2006 with an accompanying 1-page preface detailed its rationale, aims and vision. The journal was launched primarily to publish original research articles and reviews dealing with applications of global Earth observation systems (GEOS) tools to enhance human and animal health and wellbeing. Hence, since the beginning, it was suggested that Geospatial Health should become a source of vital information on the availability, application and integrated use of GIS, remote sensing and spatial analysis in human and veterinary medicine, to promote geospatial techniques for mapping, risk profiling, monitoring and surveillance, and to encourage studies of the potential, or real, impact of climate change.

As emphasized by the editor-in-chief in the settingthe-scene preface, "GEOS has come into its own in this present age of information technology and can indeed provide the necessary data regarding the spatial and climatic parameters which determine the distribution limits of communicable (parasitic) diseases at various scales such as, for example, at the district, country or regional levels. Geospatial Health should aim to harness these advantages and to serve as a forum for discussion and publication of epidemiological data in a geographical context. It is evident that the tools are as complex as the disciplines studied, thus a high-level of expertise is essential, not only for the presentation and analysis of the various data but also for the technologies used for data collection". Overall, it was felt that Geospatial Health would provide cross-fertilization between technical and health-oriented disciplines, covering the full spectrum from innovation to validation and application.

\section{The editorial board}

Geospatial Health is managed by an editor-in-chief and two associate editors, based in Europe. They do the bulk of day-to-day journal work, including e-mail exchange with authors and referees, final disposition of manuscript acceptance and specific requests for revisions, copy-editing of advanced manuscript drafts, proof setting and checking prior to sending galley proofs to authors. This core team is supported by five regional editors, based in Africa, Asia, Europe, Latin America and North America. The original editorial board consisted of 23 members, most of them European $(\mathrm{n}=10)$ and North American ( $\mathrm{n}=8$ ), whereas the remaining five are from Africa $(n=2)$, Asia $(\mathrm{n}=2)$ and Latin America $(\mathrm{n}=1)$.

After an initial term of five years, all editorial board members were invited to re-assess their interest, roles and responsibilities to act as editors on Geospatial 
Health. Several board members took this opportunity to step down and let younger peers serve on the journal's editorial board. While recruiting new board members, efforts are made to seek for a regional editor and new board members from Oceania, as we are currently lacking representation from this area. Additionally, we aim to enhance gender balance, as our editorial board currently consists of considerably more males than females. Both these issues are important and inequities have been observed while scrutinizing the editorial board composition of leading journals of general medicine and tropical medicine (Keiser et al., 2003, 2004; Falagas et al., 2006).

\section{Basic factors}

Geospatial Health is published in English by the University of Naples Federico II and the contents can be accessed electronically, free of charge, at the journal website: http://www.geospatialhealth.unina.it/index.php. The journal is issued biannually both in print (ISSN 1827-1987) and online (ISSN 1970-7096). Its openaccess policy means that readers can download all articles including illustrations in full length. It is indexed by major databases:

- CABI (Centre for Agriculture and Biosciences International, a not-for-profit organization providing information and databases in the life sciences; http://www.cabi.org/);

- PubMed and PubMed Central (free digital database of full-text scientific literature in the biomedical and life sciences, mainly based on the Medline. This database is maintained by the U.S. National Library of Medicine and the National Institutes of Health in the United States; http://www.ncbi.nlm. nih.gov); and

- ISI Web of Science (online academic citation index provided by Thomson Reuters; http://apps.webofknowledge.com).

In 2008, Geospatial Health was issued its first impact factor (i.e. 1.47), which has since gradually increased and is currently 1.71 (2010). In the ISI's Journal Citation Report (JCR), Geospatial Health is categorized under "Health Care Sciences \& Services" (in 2010, it ranked at position 35 out of 72 indexed journals) and "Public, Environmental \& Occupational Health" (ranking at position 64 out of 142 indexed journals).

\section{Bibliometric analysis}

As articulated in the aims and scope, the focus of Geospatial Health is on "all aspects of the application of GIS, remote sensing and other spatial analysis tools in human and veterinary health". Currently, five years into publication activities, we were motivated to conduct a detailed bibliometric analysis of all papers published so far. Hence, we examined the 133 contributions that are included in the first 10 issues of Geospatial Health. Emphasis is placed on publication type, number of authors per paper and country of contributing authors. For the latter analysis, we employed the 2011 human development index (HDI), which stratifies countries into: (i) very high, HDI rank 1 (Norway) to 47 (Barbados); (ii) high, HDI rank 48 (Uruguay) to 94 (Tunisia); (iii) medium, HDI rank 95 (Jordan) to 141 (Bhutan); and (iv) low, HDI rank 142 (Solomon Islands) to 187 (Democratic Republic of the Congo) (UNDP, 2011).

To get a holistic view of the origin, thematic focus and impact of articles accepted for publication, we performed a content analysis based on title, abstract and keywords of individual contributions. This analysis was restricted to original research articles and reviews $(n=116)$, whereas editorials were excluded, as they usually do not contain an abstract. In a first step, we determined whether articles had a focus on human or veterinary health. Next, we investigated the geographic (i.e. global, Africa, Asia, Europe, Latin America, North America and Oceania) and thematic foci. Research themes were grouped into disease (e.g. avian influenza, malaria, schistosomiasis, etc.), injury or risk factor (e.g. alcohol consumption). We also determined geospatial tools employed (e.g. GIS, remote sensing and spatial analysis) and did some further characterization (e.g. use of mathematical modelling, mapping, etc.).

\section{Publication type}

Our analysis of all the contributions $(\mathrm{n}=133)$ covered in the first five volumes (10 issues) of Geospatial Health published between November 2006 and May 2011 revealed that original research accounted for four out of five publications (Fig. 1). The second most important publication type $(\mathrm{n}=10,7.5 \%)$ were the reviews (Fuentes, 2006; Rinaldi et al., 2006; Gazzinelli and Kloss, 2007; Leonardo et al., 2007; Martin et al., 2007; Bernardi, 2008; Marechal et al., 2008; Stensgaard et al., 2009; Ocaña-Riola, 2010; Machault et al., 2011). So far, four editorials have been published, two invited guest editorials in the inaugural issue (Cline, 2006; Crump, 2006), and two unsolicited editorials from journal board members (Brooker and Utzinger, 2007) and other contributors (Seifter et al., 
2010). In addition, eight announcements, four meeting reports and a 1-page preface "setting-the-stage" piece (Bergquist, 2006) have been published, but these were not considered further in the subsequent analyses as they are usually put forth by the editors without external peer-review.

\section{Who publishes in Geospatial Health?}

The configuration of authors who utilized Geospatial Health as an outlet of their research has been determined by examining original research articles, reviews and editorials $(\mathrm{n}=120)$. Fig. 2 shows a histogram, displaying the number of authors per publication, stratified by these three publication types. The distribution is slightly skewed with a peak of five authors per paper and a median of six. There are 10 single-authored pieces, half of them editorials and reviews (Cline, 2006; Crump, 2006; Fuentes, 2006; Bernardi, 2008; Ocaña-Riola, 2010), and the other half presenting original research (Aron, 2006; Lwasa, 2007; Murad, 2008; Estrada-Peña, 2009; Livingston, 2010). Eight papers, all of them original research, where co-authored by at least 10 and up to 15 individuals, interestingly often stemming from P.R. China (Chen et al., 2007; Steinmann et al., 2007; Dongus et al., 2009; Li et al., 2009; Masuoka et al., 2010; Yang et al., 2010; Peng et al., 2011; Suwannatrai et al., 2011).

Taken together, these 120 publications were written by 644 authors. However, some of the authors contributed to more than one article, as shown in Table 1. Indeed, the current champion is Dr. Penelope Vounatsou, a Bayesian disease mapping and modelling specialist based at the Swiss Tropical and Public

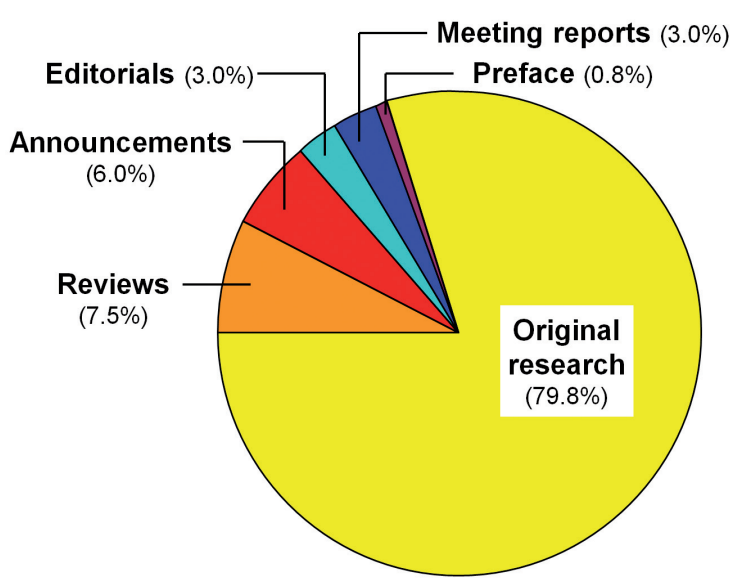

Fig. 1. Pie chart showing the percentage of publication types covered in the first five volumes of Geospatial Health (November 2006-May 2011).

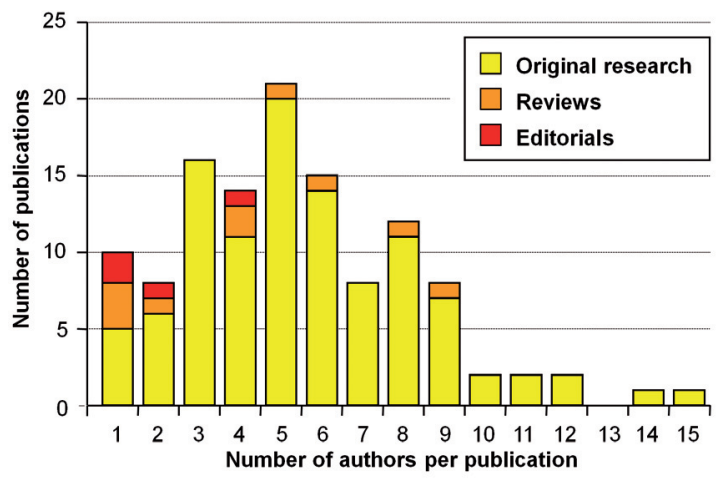

Fig. 2. Number of authors per paper in the 120 articles (original research, reviews and editorials), published in the first five volumes of Geospatial Health (November 2006-May 2011).

Health Institute (Swiss TPH) in Basel, who contributed to 10 articles. Another 12 authors (five from Italy, two from France and one each from Brazil, Denmark, P.R. China, Switzerland and the United States) contributed to 63 articles. Overall, we identified 505 unique authors who are based in 52 different countries (very high HDI, $\mathrm{n}=19$; high HDI, $\mathrm{n}=9$; medium HDI, $n=10$; low HDI, $n=14$ ).

Table 2 summarizes the geographic distribution of authors, stratified by the latest available HDI. In our analysis, we distinguished by first and corresponding author (by default, 120 each), all authors $(\mathrm{n}=644)$ and unique authors $(\mathrm{n}=505)$. As expected, there was a predominance of authors from countries with a very high

Table 1. Number of contributions by individual authors to the 120 publications (original research, reviews and editorials) published in the first five volumes of Geospatial Health (November 2006-May 2011).

\begin{tabular}{|c|c|c|}
\hline $\begin{array}{l}\text { Number of } \\
\text { contribution(s) }\end{array}$ & $\begin{array}{l}\text { Number of } \\
\text { author(s) }\end{array}$ & Country of author (n) \\
\hline 10 & 1 & Switzerland \\
\hline 9 & 1 & Switzerland \\
\hline 6 & 4 & Italy (3), P.R. China (1) \\
\hline 5 & 2 & Italy (1), United States (1) \\
\hline 4 & 5 & $\begin{array}{l}\text { France (2), Brazil (1), Denmark (1), } \\
\text { Italy (1) }\end{array}$ \\
\hline 3 & 14 & $\begin{array}{l}\text { United States (4), P.R. China (3), } \\
\text { France (2), Switzerland (2), Italy } \\
\text { (1), Spain (1), Sweden (1) }\end{array}$ \\
\hline 2 & 49 & $\begin{array}{l}\text { United States (14), Italy (8), India } \\
\text { (4), Switzerland (3), Australia (2), } \\
\text { Belgium (2), Denmark (2), France } \\
\text { (2), P.R. China (2), Brazil (1), } \\
\text { Germany (1), Malawi (1), Mali (1), } \\
\text { Senegal (1), South Africa (1), } \\
\text { Sweden (1), Uganda (1), United } \\
\text { Kingdom (1), Zambia (1) }\end{array}$ \\
\hline 1 & 431 & 52 different countries \\
\hline
\end{tabular}


Table 2. Country origin of all contributing authors to the 120 publications (original research, reviews and editorials) published in the first five volumes of Geospatial Health (November 2006-May 2011).

\begin{tabular}{lccccc}
\hline \multirow{2}{*}{ Authorship } & \multirow{2}{*}{ Number of authors } & \multicolumn{4}{c}{ Number $(\%)$ of authors, stratified by human development index (HDI) in 2011 } \\
\cline { 3 - 6 } & \multicolumn{2}{c}{ Very high } & High & Medium & Low \\
\hline All authors & 644 & $423.2(65.7)$ & $50(7.8)$ & $122.5(19.0)$ & $48.3(7.5)$ \\
Unique authors & 505 & $311.2(61.6)$ & $46(9.1)$ & $104.5(20.7)$ & $43.3(8.6)$ \\
First author & 120 & $87.7(73.1)$ & $9(7.5)$ & $18(15.0)$ & $5.3(4.4)$ \\
Corresponding author & 120 & $88.2(73.5)$ & $9(7.5)$ & $17.5(14.6)$ & $5.3(4.4)$ \\
\hline
\end{tabular}

${ }^{\text {a }}$ Source: UNDP (2011)

or a high HDI, contributing to $70.7 \%$ (unique authors) and up to $81.0 \%$ of authorship (corresponding author). Nevertheless, almost one third of the unique authors are based in countries with low or medium HDI $(29.3 \%)$, which is distinctively different from prior analyses focussing on the core tropical medicine literature (Glover and Bowen, 2004; Keiser et al., 2004; Keiser and Utzinger, 2005; Falagas et al., 2006). It is also noteworthy that 10 publications were uniquely written by authors from low HDI (Tanzania and Uganda) (Lwasa, 2007; Mboera et al., 2010) or medium HDI (India, P.R. China and Philippines) (Chen et al., 2007; Leonardo et al., 2007; Jayakumar et al., 2009; Bhunia et al., 2010; Chiang et al., 2010; Wen et al., 2010; Bhunia et al., 2011; Peng et al., 2011).

Table 3 gives a summary of the 15 countries with the largest share of authors having contributed to the 120 original research articles, reviews and editorials published in the first five volumes of Geospatial Health.
Although the United States' share of scientific articles published in the peer-reviewed literature has declined over the last decades (Hill et al., 2007), this country emerged as the single most contributing nation; more than 100 out of the 505 unique authors are based in the United States $(21.1 \%)$. Perhaps surprisingly, Italy and P.R. China followed at positions 2 and 3 in terms of country-specific contributions with shares of $11.3 \%$ and $10.4 \%$, respectively, according to unique authorship contributions. Taken together, authors from the United States, Italy and P.R. China contributed more than $40 \%$ of all the publications in the first 10 issues of Geospatial Health.

\section{Thematic and geographic focus}

As shown in Fig. 3, three quarters of the original research articles and reviews published so far in Geospatial Health focussed on human health, whereas

Table 3. The 15 most contributing countries, as determined by authors' affiliations, in the 120 publications (original research, reviews and editorials) published in the first five volumes of Geospatial Health (November 2006-May 2011).

\begin{tabular}{|c|c|c|c|c|c|}
\hline \multirow{2}{*}{ Country } & \multirow{2}{*}{$\begin{array}{l}\text { HDI } 2011 \\
(\text { HDI rank })^{\mathrm{a}}\end{array}$} & \multicolumn{4}{|c|}{ Number $(\%)$ of authors } \\
\hline & & All & Unique & First & Corresponding \\
\hline All & & $644(100)$ & $505(100)$ & $120(100)$ & $120(100)$ \\
\hline United States & $4(\mathrm{VH})$ & $133.5(20.7)$ & $106.5(21.1)$ & $28.5(23.8)$ & $28.5(23.8)$ \\
\hline Italy & $24(\mathrm{VH})$ & $90(14.0)$ & $57(11.3)$ & $17(14.2)$ & $17(14.2)$ \\
\hline P.R. China & $101(\mathrm{M})$ & $65.5(10.2)$ & $52.5(10.4)$ & $9(7.5)$ & $8.5(7.1)$ \\
\hline Switzerland & $11(\mathrm{VH})$ & $45.8(7.1)$ & $21.8(4.3)$ & $7.8(6.5)$ & $8.8(7.4)$ \\
\hline France & $20(\mathrm{VH})$ & $35.5(5.5)$ & $24.5(4.9)$ & $7(5.8)$ & $6(5.0)$ \\
\hline Brazil & $84(\mathrm{H})$ & $27(4.2)$ & $23(4.6)$ & $5(4.2)$ & $5(4.2)$ \\
\hline Thailand & $103(\mathrm{M})$ & $20(3.1)$ & $20(4.0)$ & $2(1.7)$ & $2(1.7)$ \\
\hline India & $134(\mathrm{M})$ & $17(2.6)$ & $13(2.6)$ & $3(2.5)$ & $3(2.5)$ \\
\hline Tanzania & $152(\mathrm{~L})$ & $14.8(2.3)$ & $14.8(2.9)$ & $1.3(1.1)$ & $1.3(1.1)$ \\
\hline Canada & $6(\mathrm{VH})$ & $14(2.2)$ & $14(2.8)$ & $3(2.5)$ & $3(2.5)$ \\
\hline United Kingdom & $28(\mathrm{VH})$ & $13.5(2.1)$ & $12.5(2.5)$ & $3(2.5)$ & $2(1.7)$ \\
\hline Australia & $2(\mathrm{VH})$ & $13(2.0)$ & $10(2.0)$ & $5(4.2)$ & $5(4.2)$ \\
\hline Denmark & $16(\mathrm{VH})$ & $13(2.0)$ & $8(1.6)$ & $2(1.7)$ & $2(1.7)$ \\
\hline Germany & $9(\mathrm{VH})$ & $12.3(1.9)$ & $11.3(2.2)$ & $2.3(1.9)$ & $3.3(2.8)$ \\
\hline Belgium & $18(\mathrm{VH})$ & $11.5(1.8)$ & $9.5(1.9)$ & $2(1.7)$ & $2(1.7)$ \\
\hline Remaining countries & & $117.5(18.2)$ & $106.5(21.1)$ & $22(18.3)$ & $22.5(18.8)$ \\
\hline
\end{tabular}

${ }^{\text {a }}$ Data obtained from the 2011 Human Development Report (UNDP, 2011) (HDI, human development index; VH, very high (HDI rank 1-47); H, high (HDI rank 48-94); M, medium (HDI rank 95-141); L, low (HDI rank 142-187). 
the remaining one quarter presented work related to veterinary health. We also identified six original research articles that pertained to both human and veterinary medicine (Stensgaard et al., 2006; Rossi et al., 2007; Wu et al., 2007; Infascelli et al., 2009; Sandes et al., 2009; Beugnet et al., 2011).

Fig. 4 reveals that the publication record in the first five volumes of Geospatial Health covers all parts of the world. We identified seven contributions (6.0\%) that had a global focus, five of which were reviews (Rinaldi et al., 2006; Martin et al., 2007; Bernardi, 2008; Ocaña-Riola, 2010; Machault et al., 2011) and the remaining two original research articles ( $\mathrm{Si}$ et al., 2009; Catelan and Biggeri, 2010). Approximately two thirds of the research published so far had a geographic focus on Africa, Asia and Europe, with similar shares for each of these three continents. Studies focussing on the Americas (North and Latin America) contributed one quarter, whereas only four publications $(3.4 \%)$ had an explicit focus on Oceania (East et al., 2008a,b; Wang et al., 2009; Livingston, 2010).

\section{Diseases, injuries and risk factors}

Our content analysis revealed that not less than 36 different diseases, injuries and risk factors were in the focus of the 116 original research articles and reviews published in the first five volumes of Geospatial Health. Fig. 5 shows the nine most important diseases which together account for $55.1 \%$ of the research covered. Interestingly, the "big three", that is HIV/AIDS, tuberculosis and malaria, accounted for only $13.8 \%$, whereas the neglected tropical diseases (NTDs), a cluster of mainly chronic, debilitating and poverty-related diseases (Hotez et al., 2007; Utzinger et al., 2009), contributed almost one third of the total published research. In the "big three" group, malaria was the predominant disease $(11.2 \%$ ) (Aron, 2006; Connor et al., 2006; Gosoniu et al., 2006; Kiang et al., 2006; Kazembe et al., 2007; Sogoba et al., 2007; Briët et al., 2008; Capinha et al., 2009; Dongus et al., 2009; Mboera et al., 2010; Wayant et al., 2010; Yang et al., 2010; Delgado-Petrocelli et al., 2011; Machault et al., 2011). On the other hand, HIV/AIDS and tuberculosis were discussed in only one and two studies, respectively (Zendejas-Martínez et al., 2008; Jacob et al., 2010; Peng et al., 2011).

Schistosomiasis was the predominant NTD $(11.2 \%)$; we identified 15 papers, four of which covered also another disease (Kitron et al., 2006; Stensgaard et al., 2006, 2009; Yang et al., 2006; Chen et al., 2007; Gazzinelli and Kloss, 2007; Raso et al.,
2007; Seto et al., 2007; Steinmann et al., 2007; Wu et al., 2007; Simoonga et al., 2008; Li et al., 2009; Standley et al., 2009; Filho et al., 2010; Yiannakoulias et al., 2010). The other NTDs, in descending order of importance, were leishmaniasis $(6.9 \%)$ (Nieto et al., 2006; Carneiro et al., 2007; Rossi et al., 2007; Morosetti et al., 2009; Bhunia et al., 2010; Fischer et al., 2010; Salahi-Moghaddam et al., 2010; Bhunia et al., 2011), food-borne trematodiasis $(3.7 \%)$ (Fuentes, 2006; Biggeri et al., 2007; Rinaldi et al., 2009; Suwannatrai et al., 2011), Chagas disease $(3.0 \%)$ (Kitron et al., 2006; Bustamante et al., 2007; Lambert et al., 2008; Santana et al., 2011), soil-transmitted helminthiasis and other helminth infections $(2.9 \%)$ (Biggeri et al., 2007; Raso et al., 2007; Knopp et al., 2008; Rinaldi et al., 2009; Standley et al., 2009;

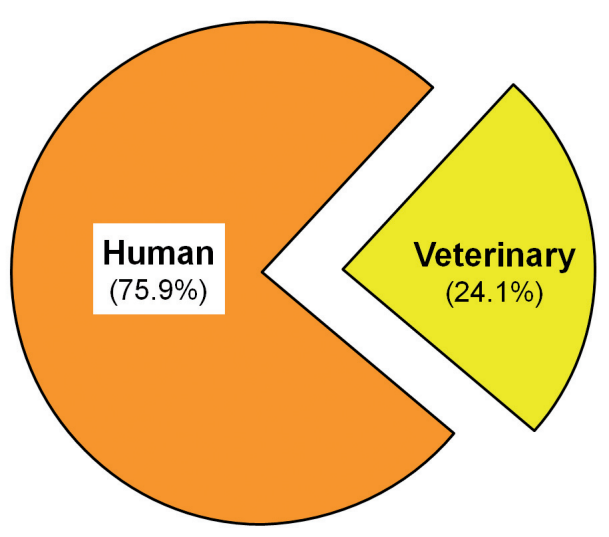

Fig. 3. Broad thematic focus (human and veterinary health) of the 116 original research articles and reviews published in the first five volumes of Geospatial Health (November 2006-May 2011).

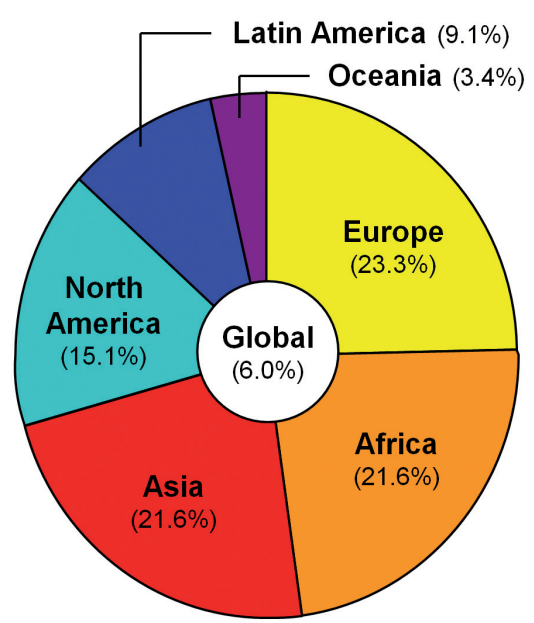

Fig. 4. Geographic focus of the 116 original research articles and reviews published in the first five volumes of Geospatial Health (November 2006-May 2011), stratified by continent. 
Yiannakoulias et al., 2010), echinococcosis (0.9\%) (Cringoli et al., 2007), rabies (0.9\%) (Mulatti et al., 2011), leprosy (0.9\%) (Argaw et al., 2006), brucellosis $(0.9 \%)$ (Porphyre et al., 2010), and filariasis $(0.9 \%)$ (Mortarino et al., 2008).

Research focussing on viral infectious diseases account for $9.5 \%$, with a predominance of Rift Valley fever $(5.2 \%)$ (Martin et al., 2007; Marechal et al., 2008; Tourre et al., 2008; Vignolles et al., 2009, 2010; Kakani et al., 2010), followed by West Nile virus (1.7\%) (LaBeaud et al., 2008; Jacob et al., 2009), dengue $(0.9 \%)$ (Tipayamongkholgul and Lisakulruk, 2011), Japanese encephalitis (0.9\%) (Masuoka et al., 2010) and Hanta virus (0.9\%) (Koch et al., 2007).

In as many as seven studies $(6.0 \%)$, tick-borne diseases were the focus of interest (Estrada-Peña et al., 2007; Estrada-Peña and Venzal, 2007; Rizzoli et al., 2007; Stein et al., 2008; Beugnet et al., 2009; EstradaPeña, 2009; Beugnet et al., 2011). The two most important animal diseases researched and published in Geospatial Health are avian influenza (H5N1), accounting for 5.2\% (Cecchi et al., 2008; East et al., 2008a, b; Fiebig et al., 2009; Si et al., 2009; Williams et al., 2011), and bluetongue with a share of $1.7 \%$ (Ducheyne et al., 2007; Willgert et al., 2011). In one veterinary study, Neospora caninum in dairy cattle in Europe was investigated (Frössling et al., 2008).

Compared to the "big three" and the NTDs, only relatively few focussed on chronic diseases, such as cancer (3.5\%) (Sturtz and Ickstadt, 2007; Catelan and Biggeri, 2008; Dreassi et al., 2008; Chiang et al., 2010; Hendryx et al., 2010), obesity (1.7\%) (Wen et al., 2010; Duncan et al., 2011), heart disease (0.9\%) (Sturtz and Ickstadt, 2007; Wang et al., 2009) and respiratory tract infection $(0.9 \%)$ (Catelan and Biggeri, 2008; Wang et al., 2009). One study focussed on a sexually-transmitted infection other than HIV/AIDS, namely gonorrhoea $(0.9 \%)$ (Theall et al., 2009). Two studies each discussed injury prevention (Cinnamon et al., 2009; Sandes et al., 2009) and (domestic) violence (Yu et al., 2008; Livingston, 2010); hence, accounting for $1.7 \%$ each.

The remaining studies discussed mental retardation in children $(1.7 \%)$ (Zhen et al., 2008, 2009), influen$\mathrm{za}$ and pneumonia (1.7\%) (Crighton et al., 2008; Tellman et al., 2010), child mortality (1.3\%) (Kazembe et al., 2007; Sartorius et al., 2011), meningococcal disease $(0.9 \%)$ (Maïnassara et al., 2010), conjunctive-uveal granuloma (0.9\%) (Jayakumar et al., 2009), alcohol outlet density and alcohol consumption (0.9\%) (Schonlau et al., 2008) and, finally, one descriptive epidemiological study with no clear disease or risk factor emphasis (Catelan and Biggeri, 2010).

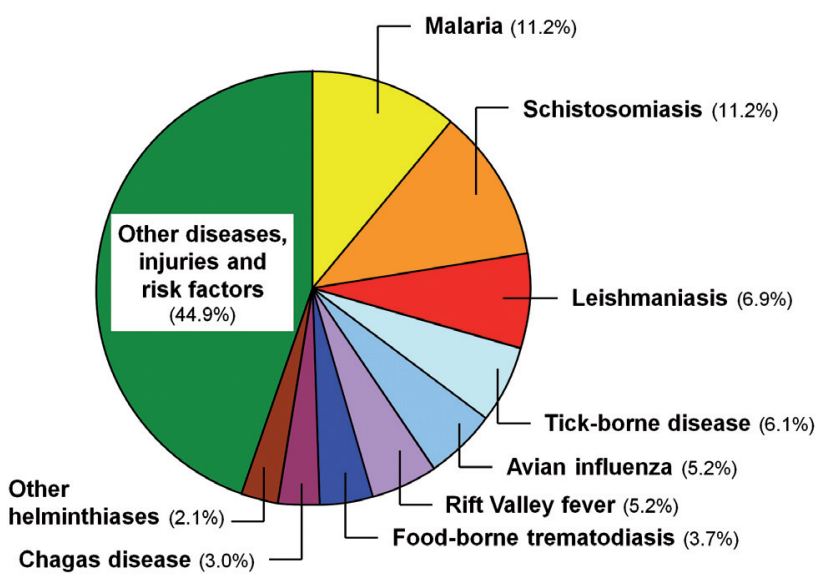

Fig. 5. Pie chart showing the nine most important diseases featured in the 116 original research articles and reviews published in the first five volumes of Geospatial Health (November 2006May 2011).

\section{Geospatial tools}

Already 25 years ago, Burrough (1986) characterized GIS as "a powerful set of tools for collecting, retrieving at will, transforming and displaying spatial data from the real world". This still holds true although slightly different definitions of GIS can appear depending on the application (Brooker and Utzinger, 2007; Simoonga et al., 2008). As shown in Fig.6, almost half of the publications in the first five volumes of Geospatial Health used GIS. Some sort of spatial analysis was performed in one third of the studies, often using advanced Bayesian geostatistics. Remote sensing applications were evident in one quarter of the studies published thus far, whereas investigations involving global positioning system (GPS) instrumentation were described only in three original research articles (Seto et al., 2007; Tourre et al., 2008; Duncan et al., 2011).

Out of the 116 original research articles and reviews, modelling and mapping were evident in $35.3 \%$ and $34.5 \%$ of the contributions, respectively. It is worth adding that simultaneous visualization of various pieces of information, e.g. data related to health and data related to the environment is one of the exceptional capabilities of GIS. Yet, only five papers mentioned the term "visualization" in the title, abstract or keywords (Murad, 2008; Pfeiffer et al., 2008; Cinnamon et al., 2009; Stensgaard et al., 2009; Widgren and Frössling, 2010). 


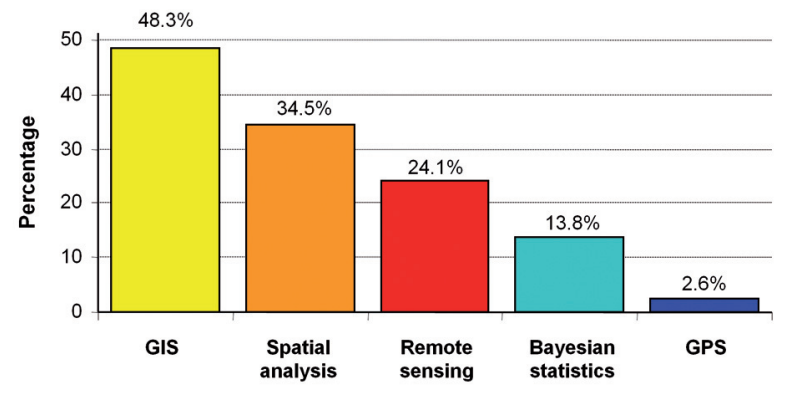

Fig. 6. Percentage of articles that made explicit mention of geospatial tools (in title, abstract and keywords) for analysing and displaying.

\section{Impact}

There are different metrics to measure the impact of scientific articles published in peer-reviewed journals, perhaps the most common of which is the ISI Web of Science-based impact factor. It takes at least two years until new journals are considered by the ISI Web of Science to receive an official impact factor. We were encouraged that our application to obtain an impact factor was granted by ISI Web of Sciences after the minimum time span of two years (first impact factor assigned in 2008). Recently, open-access journals published by the Public Library of Science (PLoS) and BioMed Central (BMC) have introduced an additional metric, namely how often a paper is accessed and downloaded. We like this concept and will explore to have this feature made available on the journal webpage.

Table 4 summarizes the characteristics and number of citations (total and stratified by year) of the 10 most highly cited papers published in the first five volumes of Geospatial Health. Interestingly, the most highly cited piece in our journal turned out to be a brief editorial, perhaps explained by the topical nature of the contribution, focussing on integrated mapping in a polyparasitic world, placing particular emphasis on malaria and NTDs (Brooker and Utzinger, 2007). Moreover, two reviews, both focussing on veterinary health issues have also been widely cited (Rinaldi et al., 2006; Martin et al., 2007). The other seven contributions that have been cited at least 10 times are original research covering a variety of diseases at different spatial scales.

\section{Outlook: visualization of a new look}

Visual and audible cues have always played a dominant role in human societies. This long perspective becomes perfectly clear when we behold the more than 35,000 years old rock carvings found in the caves of southwestern France. They may bear witness of early efforts of mass communication, but we do not know this for sure; they could just as well be ceremonial or religious. Whatever the reason, we can assume that they are the very first examples of visualization. Symbolically, the chapter can be said to have been closed on Christmas Eve in 1968 when the crew of Apollo 8 captured the first picture of planet Earth. The further development of the technology that made this possible was, however, far from closed. Much happened between these two events, but we should not to lose ourselves in endless pursuit of how the visual arts evolved. Let us instead focus on the last 50 years or so, and particularly the current situation.

Compared to classical epidemiological papers, the last decades have seen a spectacular development in the direction of much stronger visual content. This development started more than 70 years ago by the publication of the first concepts of landscape ecology, which was based on the use of aerial photography for the study of vegetation and its interactions with various types of the environment (Troll, 1939). While the modern implementation of GIS adds to visualization through maps showing disease distributions, infection risk and hotspots, Earth-observing satellites complemented this approach by data collection from the ground above which they pass. The particular attraction of satellite-based observation lays in the visible presentation of geographical structures (e.g. land cover, land use, water-bodies, elevations and manmade edifices). The merger of this information with information on the climate such as land surface temperature, normalized difference vegetation index, precipitation, etc., helped to promote the idea of infectious agents being part of the environment thereby integrating biophysical data collection and epidemiological approaches. This holistic perspective produced the notion of the landscape as a mosaic of heterogeneous areas characterized by interacting ecosystems, including emphasis on the relationship between distributions, patterns, process and scale. The flows between diverse ecological patches, relating landscape pattern analysis with landscape conservation and sustainability are the current key research topics in landscape ecology (Wu, 2006). It is encouraging to note, that four articles in Geospatial Health pertain to landscape ecology and further develop this concept into landscape epidemiology and genetics (Koch et al., 2007; Li et al., 2009; Filho et al., 2010; DelgadoPetrocelli et al., 2011). 
Table 4. Characteristics and number of citations per year of the 10 most highly cited papers published in the first five volumes of Geospatial Health (November 2006-May 2011) ${ }^{\mathrm{a}}$

\begin{tabular}{|c|c|c|c|c|c|c|c|c|c|c|}
\hline \multirow{2}{*}{ Reference } & \multirow{2}{*}{$\begin{array}{l}\text { Publication } \\
\text { type }\end{array}$} & \multirow{2}{*}{$\begin{array}{l}\text { Human }(\mathrm{H}) \text { or } \\
\text { veterinary }(\mathrm{V})\end{array}$} & \multirow{2}{*}{$\begin{array}{l}\text { Disease(s) and risk } \\
\text { factor }\end{array}$} & \multirow{2}{*}{$\begin{array}{l}\text { Geographic } \\
\text { focus }\end{array}$} & \multicolumn{6}{|c|}{ No. of citations } \\
\hline & & & & & 2007 & 2008 & 2009 & 2010 & 2011 & Total \\
\hline Brooker and Utzinger (2007) & Editorial & $\mathrm{H}$ & Malaria and NTDs & Global & 4 & 1 & 12 & 12 & 7 & 36 \\
\hline Rinaldi et al. (2006) & Review & $\mathrm{V}$ & Veterinary parasitology & Global & 7 & 1 & 10 & 5 & 4 & 27 \\
\hline Gosoniu et al. (2006) & $\begin{array}{l}\text { Original } \\
\text { research }\end{array}$ & $\mathrm{H}$ & Malaria & Mali, Africa & 2 & 5 & 4 & 5 & 9 & 25 \\
\hline Steinmann et al. (2007) & $\begin{array}{l}\text { Original } \\
\text { research }\end{array}$ & $\mathrm{H}$ & Schistosomiasis & $\begin{array}{l}\text { P.R. China, } \\
\text { Asia }\end{array}$ & 0 & 2 & 2 & 10 & 1 & 15 \\
\hline Wu et al. (2007) & $\begin{array}{l}\text { Original } \\
\text { research }\end{array}$ & $\mathrm{H}$ and $\mathrm{V}$ & Schistosomiasis & $\begin{array}{l}\text { P.R. China, } \\
\text { Asia }\end{array}$ & 0 & 2 & 4 & 7 & 0 & 14 \\
\hline Stensgaard et al. (2009) & $\begin{array}{l}\text { Original } \\
\text { research }\end{array}$ & $\mathrm{H}$ & $\begin{array}{l}\text { Schistosomiasis } \\
\text { (vector-borne diseases) }\end{array}$ & Africa & 0 & 0 & 2 & 6 & 4 & 12 \\
\hline Si et al. (2009) & $\begin{array}{l}\text { Original } \\
\text { research }\end{array}$ & $\mathrm{V}$ & Avian influenza & Global & 0 & 0 & 0 & 6 & 5 & 11 \\
\hline Schonlau et al. (2008) & $\begin{array}{l}\text { Original } \\
\text { research }\end{array}$ & $\mathrm{H}$ & Alcohol consumption & $\begin{array}{l}\text { United States, } \\
\text { North America }\end{array}$ & 0 & 0 & 3 & 3 & 5 & 11 \\
\hline Martin et al. (2007) & Review & $\mathrm{V}$ & Rift Valley fever & Global & 1 & 0 & 2 & 6 & 2 & 11 \\
\hline Kitron et al. (2006) & $\begin{array}{l}\text { Original } \\
\text { research }\end{array}$ & $\mathrm{H}$ & $\begin{array}{l}\text { Chagas disease and } \\
\text { schistosomiasis }\end{array}$ & $\begin{array}{l}\text { Argentina, } \\
\text { Latin America; } \\
\text { Kenya, Africa }\end{array}$ & 2 & 2 & 3 & 1 & 3 & 11 \\
\hline
\end{tabular}

${ }^{a}$ Data obtained from ISI Web of Knowledge (http://apps.webofknowledge.com). Database accessed on December 17, 2011)

The spatial, temporal and spectral resolution of the sensor instruments onboard satellites rapidly drew attention to the utility of computer-based models of the Earth for epidemiological research. These technical advances have not only created unprecedented opportunities to investigate local geographic variations in disease distributions, but have also presented new complexity that can only be addressed by statistics, e.g. random components that may dominate in the estimation of disease rates across small areas. For example, although smooth estimates of disease risk can be produced with Bayesian statistics, the detection of high-risk areas is limited when the expected numbers of cases are small. Naturally, data errors can result in apparent local disease excess, while disease clustering can arise non-systematically. Thus, spatial statistics are playing an increasing role in relation to epidemiology and landscape ecology. In the future, developments leading to improved modelling of exposure, risk-mapping and new methods of surveillance of large health databases promise to improve our ability to better understand the relationships between environment and health.
Representation of health data (e.g. prevalence and intensity of infection and incidence) in the form of a map facilitates interpretation, synthesis and recognition of frequency and clusters of phenomena (Rinaldi et al., 2006). One of the most useful functions of GIS in epidemiology continues to be its utility in basic mapping. Usually, when data are collected either routinely or through purposely-designed surveys, they are presented in tabular forms, which can be exploited for analytical usage. However, the reading and interpretation of such data is often a laborious and time-consuming task and does not permit easy decision-making. On the other hand, seeing the data in the form of map facilitates interpretation, synthesis and recognition of patterns. The use of the map as provider of "first glance" information is obvious nowadays. However, changing the mentality of "traditional" epidemiologists has not been easy and convincing people has been an uphill struggle despite the usefulness of visualizing health in the form of maps and diagrams.

These aspects were discussed in a symposium entitled "A picture is worth a thousand words: visualization of health using geospatial tools", held in 
Philadelphia on December 7, 2011 at the $60^{\text {th }}$ annual meeting of the American Society of Tropical Medicine and Hygiene. After an initial overview of the importance of visual presentations, different ways of visualizing information were presented (Jürg Utzinger; Swiss TPH, Basel, Switzerland). In a second presentation, classical disease risk maps and predictive maps were discussed (Amadou Garba; Réseau International Schistosomoses, Environnement, Aménagement et Lutte, Niamey, Niger). Next, it was shown how a powerpoint presentation with highly "animated pictures" can not only captivate an audience, but also succeed in transferring a much stronger visual content in less time than a classical slide show (Mirko S. Winkler; Swiss TPH, Basel, Switzerland). The final presentation, delivered by Cassandra Kirk on behalf of Gary R. Krieger (NewFields, Boulder, United States), was a 9-min long video-clip visualizing the health risk for uranium contamination in a rural mine project in Kyrgyzstan, providing an insight how this new way of information as a means to imprint in our minds a lasting memory of the risks of mining dangerous materials, something which is not always the case when text, tables or figures alone are presented.

The discussion following these presentations was both long and animated showing that it could be useful to take the lead in showcasing this new format. Indeed, the reader can easily see the difference when consulting the illustrations of this article as they represent both sides of the coin, the tables on the one hand and the figures on the other. This is not the same as arguing that the tables upon which the visual displays (the figures) are based, can be done away with. Indeed, the illustrations lose much of their force without these table underpinnings.

The follow-up of the discussions in this symposium will appear in the next issue of Geospatial Health, in which we will attempt to publish one or more pilot articles of this kind. The basic idea is to publish a few lines explaining the background to, and the need for, visualization plus tables giving the mathematical foundations for what will be published in the format of visual presentations ("animated slides" and video clips). As we enter this new era, the old adage that a picture is worth more than thousand words rings truer than ever.

\section{Acknowledgements}

We thank our dear members of the editorial board, all the authors and the external referees for their fine contributions and their continued interest in Geospatial Health. Special thanks are addressed to Giuseppe Marzatico (webmaster of the journal) and Vincenzo Musella for creating the logo on the front cover.

\section{References}

Argaw AT, Shannon EJ, Assefa A, Mikru FS, Mariam BK, Malone JB, 2006. A geospatial risk assessment model for leprosy in Ethiopia based on environmental thermal-hydrological regime analysis. Geospat Health 1, 105-113.

Aron JL, 2006. Barriers to use of geospatial data for adaptation to climate change and variability: case studies in public health. Geospat Health 1, 11-16.

Beck LR, Rodriguez MH, Dister SW, Rodriguez AD, Rejmankova E, Ulloa A, Meza RA, Roberts DR, Paris JF, Spanner MA, Washino RK, Hacker C, Legters LJ, 1994. Remote sensing as a landscape epidemiologic tool to identify villages at high risk for malaria transmission. Am J Trop Med Hyg 51, 271-280.

Bergquist R, 2006. Preface. Geospat Health 1, 1.

Bergquist R, 2011. New tools for epidemiology: a space odyssey. Mem Inst Oswaldo Cruz 106, 892-900.

Bergquist R, Malone JB, Kristensen TK, 2000. Schistosomiasis information systems and control of snail-borne diseases. Parasitol Today 16, 363-364.

Bergquist R, Rinaldi L, 2010. Health research based on geospatial tools: a timely approach in a changing environment. J Helminthol 84, 1-11.

Bernardi M, 2008. Global climate change - a feasibility perspective of its effect on human health at a local scale. Geospat Health 2, 137-150.

Beugnet F, Chalvet-Monfray K, Loukos H, 2009. FleaTickRisk: a meteorological model developed to monitor and predict the activity and density of three tick species and the cat flea in Europe. Geospat Health 4, 97-113.

Beugnet F, Kolasinski M, Michelangeli PA, Vienne J, Loukos H, 2011. Mathematical modelling of the impact of climatic conditions in France on Rhipicephalus sanguineus tick activity and density since 1960. Geospat Health 5, 255-263.

Bhunia GS, Kesari S, Chatterjee N, Pal DK, Kumar V, Ranjan A, Das P, 2011. Incidence of visceral leishmaniasis in the Vaishali district of Bihar, India: spatial patterns and role of inland water bodies. Geospat Health 5, 205-215.

Bhunia GS, Kesari S, Jeyaram A, Kumar V, Das P, 2010. Influence of topography on the endemicity of Kala-azar: a study based on remote sensing and geographical information system. Geospat Health 4, 155-165.

Biggeri A, Catelan D, Dreassi E, Rinaldi L, Musella V, Veneziano V, Cringoli G, 2007. Multivariate spatially-structured variability of ovine helminth infections. Geospat Health 2, 97-104.

Briët OJT, Vounatsou P, Amerasinghe PH, 2008. Malaria seasonality and rainfall seasonality in Sri Lanka are correlated in 
space. Geospat Health 2, 183-190.

Brooker S, 2002. Schistosomes, snails and satellites. Acta Trop 82, 207-214.

Brooker S, Michael E, 2000. The potential of geographical information systems and remote sensing in the epidemiology and control of human helminth infections. Adv Parasitol 47, 245-288.

Brooker S, Utzinger J, 2007. Integrated disease mapping in a polyparasitic world. Geospat Health 1, 141-146.

Burrough PA, 1986. Principles of geographical information systems for land resources assessment. Clarendon Press, Oxford, $220 \mathrm{p}$.

Bustamante DM, Monroy MC, Rodas AG, Juarez JA, Malone JB, 2007. Environmental determinants of the distribution of Chagas disease vectors in south-eastern Guatemala. Geospat Health 1, 199-211.

Capinha C, Gomes E, Reis E, Rocha J, Sousa CA, do Rosário VE, Almeida AP, 2009. Present habitat suitability for Anopheles atroparvus (Diptera, Culicidae) and its coincidence with former malaria areas in mainland Portugal. Geospat Health 3, 177-187.

Carneiro DDMT, Bavia ME, Rocha WJSF, Tavares ACQ, Cardim LL, Alemayehu B, 2007. Application of spatio-temporal scan statistics for the detection of areas with increased risk for American visceral leishmaniasis in the state of Bahia, Brazil. Geospat Health 2, 113-126.

Catelan D, Biggeri A, 2008. A statistical approach to rank multiple priorities in environmental epidemiology: an example from high-risk areas in Sardinia, Italy. Geospat Health 3, 8189.

Catelan D, Biggeri A, 2010. Multiple testing in disease mapping and descriptive epidemiology. Geospat Health 4, 219-229.

Ceccato P, Connor SJ, Jeanne I, Thomson MC, 2005. Application of geographical information systems and remote sensing technologies for assessing and monitoring malaria risk. Parassitologia 47, 81-96.

Cecchi G, Ilemobade A, Le Brun Y, Hogerwerf L, Slingenbergh J, 2008. Agro-ecological features of the introduction and spread of the highly pathogenic avian influenza (HPAI) H5N1 in northern Nigeria. Geospat Health 3, 7-16.

Chen Z, Zhou XN, Yang K, Wang XH, Yao ZQ, Wang TP, Yang GJ, Yang YJ, Zhang SQ, Wang J, Jia TW, Wu XH, 2007. Strategy formulation for schistosomiasis japonica control in different environmental settings supported by spatial analysis: a case study from China. Geospat Health 1, 223-231.

Chiang CT, Hwang YH, Su CC, Tsai KY, Lian Ie B, Yuan TH, Chang TK, 2010. Elucidating the underlying causes of oral cancer through spatial clustering in high-risk areas of Taiwan with a distinct gender ratio of incidence. Geospat Health 4, 230-242.

Cinnamon J, Rinner C, Cusimano MD, Marshall S, Bakele T, Hernandez T, Glazier RH, Chipman ML, 2009. Evaluating web-based static, animated and interactive maps for injury prevention. Geospat Health 4, 3-16.

Cline BL, 1970. New eyes for epidemiologists: aerial photography and other remote sensing techniques. Am J Epidemiol 92, 85-89.

Cline BL, 2006. Invited editorial for the inaugural issue of Geospatial Health. Geospat Health 1, 3-5.

Connor SJ, Ceccato P, Dinku T, Omumbo J, Grover-Kopec EK, Thomson MC, 2006. Using climate information for improved health in Africa: relevance, constraints and opportunities. Geospat Health 1, 17-31.

Crighton EJ, Elliott SJ, Kanaroglou P, Moineddin R, Upshur REG, 2008. Spatio-temporal analysis of pneumonia and influenza hospitalizations in Ontario, Canada. Geospat Health 2, 191-202.

Cringoli G, Rinaldi L, Musella V, Veneziano V, Maurelli MP, Di Pietro F, Frisiello M, Di Pietro S, 2007. Geo-referencing livestock farms as tool for studying cystic echinococcosis epidemiology in cattle and water buffaloes from southern Italy. Geospat Health 2, 105-111.

Cromley EK, 2003. GIS and disease. Annu Rev Public Health 24, 7-24.

Cross ER, Bailey RC, 1984. Prediction of areas endemic for schistosomiasis through use of discriminant analysis of environmental data. Mil Med 149, 28-30.

Cross ER, Sheffield C, Perrine R, Pazzaglia G, 1984. Predicting areas endemic for schistosomiasis using weather variables and a Landsat data base. Mil Med 149, 542-544.

Crump A, 2006. Satellite teleHealth: good for the cutting edge and in the bush? Geospat Health 1, 7-10.

Delgado-Petrocelli L, Camardiel A, Aguilar VH, Martinez N, Córdova K, Ramos S, 2011. Geospatial tools for the identification of a malaria corridor in Estado Sucre, a Venezuelan north-eastern state. Geospat Health 5, 169-176.

Dongus S, Nyika D, Kannady K, Mtasiwa D, Mshinda H, Gosoniu L, Drescher AW, Fillinger U, Tanner M, Killeen GF, Castro MC, 2009. Urban agriculture and Anopheles habitats in Dar es Salaam, Tanzania. Geospat Health 3, 189-210.

Dreassi E, Lagazio C, Maule MM, Magnani C, Biggeri A, 2008. Sensitivity analysis of the relationship between disease occurrence and distance from a putative source of pollution. Geospat Health 2, 263-271.

Ducheyne E, De Deken R, Bécu S, Codina B, Nomikou K, Mangana-Vougiaki O, Georgiev G, Purse BV, Hendickx G, 2007. Quantifying the wind dispersal of Culicoides species in Greece and Bulgaria. Geospat Health 1, 177-189.

Duncan DT, Castro MC, Blossom JC, Bennett GG, Gortmaker SL, 2011. Evaluation of the positional difference between two common geocoding methods. Geospat Health 5, 265-273.

East IJ, Hamilton S, Garner G, 2008a. Identifying areas of Australia at risk of $\mathrm{H} 5 \mathrm{~N} 1$ avian influenza infection from exposure to migratory birds: a spatial analysis. Geospat Health 2, 
203-213.

East IJ, Hamilton S, Sharp LA, Garner MG, 2008b. Identifying areas of Australia at risk for H5N1 avian influenza infection from exposure to nomadic waterfowl moving throughout the Australo-Papuan region. Geospat Health 3, 17-27.

Estrada-Peña A, 2009. Diluting the dilution effect: a spatial Lyme model provides evidence for the importance of habitat fragmentation with regard to the risk of infection. Geospat Health 3, 143-155.

Estrada-Peña A, Vatansever Z, Gargili A, Buzgan T, 2007. An early warning system for Crimean-Congo haemorrhagic fever seasonality in Turkey based on remote sensing technology. Geospat Health 2, 127-135.

Estrada-Peña A, Venzal JM, 2007. A GIS framework for the assessment of tick impact on human health in a changing climate. Geospat Health 1, 157-168.

Falagas ME, Karavasiou AI, Bliziotis IA, 2006. A bibliometric analysis of global trends of research productivity in tropical medicine. Acta Trop 99, 155-159.

Fiebig L, Smieszek T, Saurina J, Hattendorf J, Zinsstag J, 2009. Contacts between poultry farms, their spatial dimension and their relevance for avian influenza preparedness. Geospat Health 4, 79-95.

Filho FA, Sant'Ana JM, Santos RF, Castagna CL, 2010. Environmental inducers of schistosomiasis mansoni in Campinas, Brazil. Geospat Health 5, 79-91.

Fischer D, Thomas SM, Beierkuhnlein C, 2010. Temperaturederived potential for the establishment of phlebotomine sandflies and visceral leishmaniasis in Germany. Geospat Health 5, 59-69.

Frössling J, Nødtvedt A, Lindberg A, Björkman C, 2008. Spatial analysis of Neospora caninum distribution in dairy cattle from Sweden. Geospat Health 3, 39-45.

Fuentes MV, 2006. Remote sensing and climate data as a key for understanding fasciolosis transmission in the Andes: review and update of an ongoing interdisciplinary project. Geospat Health 1, 59-70.

Gazzinelli A, Kloss H, 2007. The use of spatial tools in the study of Schistosoma mansoni and its intermediate host snails in Brazil: a brief review. Geospat Health 2, 51-58.

Glover SW, Bowen SL, 2004. Bibliometric analysis of research published in tropical medicine and international health 19962003. Trop Med Int Health 9, 1327-1330.

Gosoniu L, Vounatsou P, Sogoba N, Smith T, 2006. Bayesian modelling of geostatistical malaria risk data. Geospat Health 1, 127-139.

Hay SI, Omumbo JA, Craig MH, Snow RW, 2000. Earth observation, geographic information systems and Plasmodium falciparum malaria in sub-Saharan Africa. Adv Parasitol 47, 173215.

Hay SI, Tucker CJ, Rogers DJ, Packer MJ, 1996. Remotely sensed surrogates of meteorological data for the study of the distribution and abundance of arthropod vectors of disease. Ann Trop Med Parasitol 90, 1-19.

Hendryx M, Fedorko E, Anesetti-Rothermel A, 2010. A geographical information system-based analysis of cancer mortality and population exposure to coal mining activities in West Virginia, United States of America. Geospat Health 4, 243256.

Hill D, Rapoport AI, Lehming RF, Bell RK, 2007. Changing U.S. output of scientific articles: 1988-2003. Special Report, National Science Foundation.

Hotez PJ, Molyneux DH, Fenwick A, Kumaresan J, Ehrlich Sachs S, Sachs JD, Savioli L, 2007. Control of neglected tropical diseases. N Engl J Med 357, 1018-1027.

Infascelli R, Pelorosso R, Boccia L, 2009. Spatial assessment of animal manure spreading and groundwater nitrate pollution. Geospat Health 4, 27-38.

Jacob BJ, Gu WD, Caamano EX, Novak RJ, 2009. Developing operational algorithms using linear and non-linear squares estimation in Python for the identification of Culex pipiens and Culex restuans in a mosquito abatement district (Cook county, Illinois, USA). Geospat Health 3, 157-176.

Jacob BJ, Krapp F, Ponce M, Gottuzzo E, Griffith DA, Novak RJ, 2010. Accounting for autocorrelation in multi-drug resistant tuberculosis predictors using a set of parsimonious orthogonal eigenvectors aggregated in geographic space. Geospat Health 4, 201-217.

Jayakumar D, Kavitha S, Rathinam S, Vasanthi G, 2009. Geomapping of trematode-induced granulomatous anterior uveitis - a newly identified cause of blindness among children in the Pudukkottai district of the Tamil Nadu state, India. Geospat Health 4, 55-63.

Kakani S, LaBeaud AD, King CH, 2010. Planning for Rift Valley fever virus: use of geographical information systems to estimate the human health threat of white-tailed deer (Odocoileus virginianus)-related transmission. Geospat Health 5, 33-43.

Kazembe LN, Appleton CC, Kleinschmidt I, 2007. Spatial analysis of the relationship between early childhood mortality and malaria endemicity in Malawi. Geospat Health 2, 41-50.

Keiser J, Utzinger J, 2005. Trends in the core literature on tropical medicine: a bibliometric analysis from 1952-2002. Scientometrics 62, 351-365.

Keiser J, Utzinger J, Singer BH, 2003. Gender composition of editorial boards of general medical journals. Lancet 362, 1336.

Keiser J, Utzinger J, Tanner M, Singer BH, 2004. Representation of authors and editors from countries with different human development indexes in the leading literature on tropical medicine: survey of current evidence. BMJ 328, 1229-1232.

Khan OA, Davenhall W, Ali M, Castillo-Salgado C, VazquezProkopec G, Kitron U, Soares Magalhaes RJ, Clements ACA, 2011. Geographical information systems and tropical medi- 
cine. Ann Trop Med Parasitol 104, 303-318.

Kiang R, Adimi F, Soika V, Nigro J, Singhasivanon P, Sirichaisinthop J, Leemingsawat S, Apiwathnasorn C, Looareesuwan S, 2006. Meteorological, environmental remote sensing and neural network analysis of the epidemiology of malaria transmission in Thailand. Geospat Health 1, 71-84.

Kistemann T, Dangendorf F, Schweikart J, 2002. New perspectives on the use of geographical information systems (GIS) in environmental health sciences. Int J Hyg Environ Health 205, 169-181.

Kitron U, Clennon JA, Cecere MC, Gürtler RE, King CH, Vazquez-Prokopec G, 2006. Upscale or downscale: applications of fine scale remotely sensed data to Chagas disease in Argentina and schistosomiasis in Kenya. Geospat Health 1, 49-58.

Knopp S, Mohammed KA, Khamis IS, Mgeni AF, Stothard JR, Rollinson D, Marti H, Utzinger J, 2008. Spatial distribution of soil-transmitted helminths, including Strongyloides stercoralis, among children in Zanzibar. Geospat Health 3, 47-56.

Koch DE, Mohler RL, Goodin DG, 2007. Stratifying land use/land cover for spatial analysis of disease ecology and risk: an example using object-based classification techniques. Geospat Health 2, 15-28.

LaBeaud AD, Gorman AM, Koonce J, Kippes C, McLeod J, Lynch J, Gallagher T, King CH, Mandalakas AM, 2008. Rapid GIS-based profiling of West Nile virus transmission: defining environmental factors associated with an urban-suburban outbreak in Northeast Ohio, USA. Geospat Health 2, 215-225.

Lambert RC, Kolivras KN, Resler LM, Brewster CC, Paulson SL, 2008. The potential for emergence of Chagas disease in the United States. Geospat Health 2, 227-239.

Leonardo LR, Crisostomo BA, Solon JAA, Rivera PT, Marcelo $\mathrm{AB}$, Villasper JM, 2007. Geographical information systems in health research and services delivery in the Philippines. Geospat Health 1, 147-155.

Li SZ, Wang YX, Yang K, Liu Q, Wang Q, Zhang Y, Wu XH, Guo JG, Bergquist R, Zhou XN, 2009. Landscape genetics: the correlation of spatial and genetic distances of Oncomelania hupensis, the intermediate host snail of Schistosoma japonicum in mainland China. Geospat Health 3, 221-231.

Livingston M, 2010. The ecology of domestic violence: the role of alcohol outlet density. Geospat Health 5, 139-149.

Lwasa S, 2007. Geospatial analysis and decision support for health services planning in Uganda. Geospat Health 2, 29-40.

Machault V, Vignolles C, Borchi F, Vounatsou P, Pages F, Briolant S, Lacaux JP, Rogier C, 2011. The use of remotely sensed environmental data in the study of malaria. Geospat Health 5, 151-168.

Maïnassara HB, Molinari N, Dematteï C, Fabbro-Peray P, 2010. The relative risk of spatial cluster occurrence and spatiotemporal evolution of meningococcal disease in Niger,
2002-2008. Geospat Health 5, 93-101.

Malone JB, Bergquist NR, Huh OK, Bavia ME, Bernardi M, El Bahy MM, Fuentes MV, Kristensen TK, McCarroll JC, Yilma JM, Zhou XN, 2001. A global network for the control of snail-borne disease using satellite surveillance and geographic information systems. Acta Trop 79, 7-12.

Malone JB, Fehler DP, Loyacano AF, Zukowski SH, 1992. Use of LANDSAT MSS imagery and soil type in a geographic information system to assess site-specific risk of fascioliasis on Red River Basin farms in Louisiana. Ann N Y Acad Sci 653, 389-397.

Malone JB, Gommes R, Hansen J, Yilma JM, Slingenberg J, Snijders F, Nachtergaele F, Ataman E, 1998. A geographic information system on the potential distribution and abundance of Fasciola hepatica and F. gigantica in East Africa based on Food and Agriculture Organization databases. Vet Parasitol 78, 87-101.

Malone JB, Huh OK, Fehler DP, Wilson PA, Wilensky DE, Holmes RA, Elmagdoub AI, 1994. Temperature data from satellite imagery and the distribution of schistosomiasis in Egypt. Am J Trop Med Hyg 50, 714-722.

Marechal F, Ribeiro N, Lafaye M, Güell A, 2008. Satellite imaging and vector-borne diseases: the approach of the French National Space Agency (CNES). Geospat Health 3, 1-5.

Martin V, De Simone L, Lubroth J, Ceccato P, Chevalier V, 2007. Perspectives on using remotely-sensed imagery in predictive veterinary epidemiology and global early warning systems. Geospat Health 2, 3-14.

Masuoka P, Klein TA, Kim HC, Claborn DM, Achee N, Andre R, Chamberlin J, Small J, Anyamba A, Lee DK, Yi SH, Sardelis M, Ju YR, Grieco J, 2010. Modeling the distribution of Culex tritaeniorhynchus to predict Japanese encephalitis distribution in the Republic of Korea. Geospat Health 5, 45-57.

Maxcy KF, 1923. The distribution of malaria in the United States as indicated by mortality reports. Public Health Reports 38, 1125-1138.

Mboera LEG, Senkoro KP, Mayala BK, Rumisha SF, Rwegoshora RT, Mlozi MRS, Shayo EH, 2010. Spatio-temporal variation in malaria transmission intensity in five agroecosystems in Mvomero district, Tanzania. Geospat Health 4, 167-178.

Morosetti G, Bongiorno G, Beran B, Scalone A, Moser J, Gramiccia M, Gradoni L, Maroli M, 2009. Risk assessment for canine leishmaniasis spreading in the north of Italy. Geospat Health 4, 115-127.

Mortarino M, Musella V, Costa V, Genchi C, Cringoli G, Rinaldi L, 2008. GIS modeling for canine dirofilariosis risk assessment in central Italy. Geospat Health 2, 253-261.

Mulatti P, Ferrè N, Patregnani T, Bonfanti L, Marangon S, 2011. Geographical information systems in the management of the 2009-2010 emergency oral anti-rabies vaccination of foxes in north-eastern Italy. Geospat Health 5, 217-226. 
Murad AA, 2008. Defining health catchment areas in Jeddah city, Saudi Arabia: an example demonstrating the utility of geographical information systems. Geospat Health 2, 151160.

Nieto P, Malone JB, Bavia ME, 2006. Ecological niche modeling for visceral leishmaniasis in the state of Bahia, Brazil, using genetic algorithm for rule-set prediction and growing degree day-water budget analysis. Geospat Health 1, 115-126.

Ocaña-Riola R, 2010. Common errors in disease mapping. Geospat Health 4, 139-154.

Peng ZH, Cheng YJ, Reilly KH, Wang L, Qin QQ, Ding ZW, Ding GW, Ding KQ, Yu RB, Chen F, Wang N, 2011. Spatial distribution of HIV/AIDS in Yunnan province, People's Republic of China. Geospat Health 5, 177-182.

Pfeiffer C, Glaser S, Vencatesan J, Schliermann-Kraus E, Drescher A, Glaser R, 2008. Facilitating participatory multilevel decision-making by using interactive mental maps. Geospat Health 3, 103-112.

Porphyre T, Jackson R, Sauter-Louis C, Ward D, Baghyan G, Stepanyan E, 2010. Mapping brucellosis risk in communities in the Republic of Armenia. Geospat Health 5, 103-118.

Raso G, Vounatsou P, McManus DP, Utzinger J, 2007. Bayesian risk maps for Schistosoma mansoni and hookworm monoinfections in a setting where both parasites co-exist. Geospat Health 2, 85-96.

Rinaldi L, Musella V, Biggeri A, Cringoli G, 2006. New insights into the application of geographical information systems and remote sensing in veterinary parasitology. Geospat Health 1 , 33-47.

Rinaldi L, Musella V, Veneziano V, Condoleo RU, Cringoli G, 2009. Helmintic infections in water buffaloes on Italian farms: a spatial analysis. Geospat Health 3, 233-239.

Rizzoli A, Neteler M, Rosà R, Versini W, Cristofolini A, Bregoli M, Buckley A, Gould EA, 2007. Early detection of tick-borne encephalitis virus spatial distribution and activity in the province of Trento, northern Italy. Geospat Health 1, 169176.

Rogers DJ, Hay SI, Packer MJ, 1996. Predicting the distribution of tsetse flies in West Africa using temporal Fourier processed meteorological satellite data. Ann Trop Med Parasitol 90, 225-241.

Rossi E, Rinaldi L, Musella V, Veneziano V, Carbone S, Gradoni L, Cringoli G, Maroli M, 2007. Mapping the main Leishmania phlebotomine vector in the endemic focus of the Mt. Vesuvius in southern Italy. Geospat Health 1, 191-198.

Salahi-Moghaddam A, Mohebali M, Moshfae A, Habibi M, Zarei Z, 2010. Ecological study and risk mapping of visceral leishmaniasis in an endemic area of Iran based on a geographical information systems approach. Geospat Health 5, 71-77. Sandes RL, Jr., Oliveira CL, Ferreira ES, Cruiff E, Tavares C, Santos ACB, Franke CR, Bavia ME, 2009. Spatial analysis of migrating Apis mellifera colonies in Salvador, Bahia, Brazil.
Geospat Health 4, 129-134.

Santana KSO, Bavia ME, Lima AD, Guimarães ICS, Soares ES, Silva MMN, Mendonça J, Martin MS, 2011. Spatial distribution of triatomines (Reduviidae: Triatominae) in urban areas of the city of Salvador, Bahia, Brazil. Geospat Health 5, 199203.

Sartorius B, Kahn K, Collinson MA, Vounatsou P, Tollman SM, 2011. Survived infancy but still vulnerable: spatial-temporal trends and risk factors for child mortality in the Agincourt rural sub-district, South Africa, 1992-2007. Geospat Health 5, 285-295.

Schonlau M, Scribner R, Farley TA, Theall K, Bluthenthal RN, Scott M, Cohen DA, 2008. Alcohol outlet density and alcohol consumption in Los Angeles county and southern Louisiana. Geospat Health 3, 91-101.

Seifter A, Schwarzwalder A, Geis K, Aucott J, 2010. The utility of "Google Trends" for epidemiological research: Lyme disease as an example. Geospat Health 4, 135-137.

Seto EYW, Knapp F, Zhong B, Yang CH, 2007. The use of a vest equipped with a global positioning system to assess water-contact patterns associated with schistosomiasis. Geospat Health 1, 233-241.

Si Y, Skidmore AK, Wang TJ, de Boer WF, Debba P, Toxopeus AG, Li L, Prins HHT, 2009. Spatio-temporal dynamics of global H5N1 outbreaks match bird migration patterns. Geospat Health 4, 65-78.

Simoonga C, Kazembe LN, Kristensen TK, Olsen A, Appleton CC, Mubita P, Mubila L, 2008. The epidemiology and smallscale spatial heterogeneity of urinary schistosomiasis in Lusaka province, Zambia. Geospat Health 3, 57-67.

Simoonga C, Utzinger J, Brooker S, Vounatsou P, Appleton CC, Stensgaard AS, Olsen A, Kristensen TK, 2009. Remote sensing, geographical information system and spatial analysis for schistosomiasis epidemiology and ecology in Africa. Parasitology 136, 1683-1693.

Smith AJ, 1903. Uncinariasis in Texas. Am J Med Sci 126, 768798.

Snow J, 1855. On the mode of communication of cholera, 2nd ed. John Churchill, London, 139 p.

Sogoba N, Vounatsou P, Bagayoko MM, Doumbia S, Dolo G, Gosoniu L, Traore SF, Toure YT, Smith T, 2007. The spatial distribution of Anopheles gambiae sensu stricto and An. arabiensis (Diptera: Culicidae) in Mali. Geospat Health 1, 213 222.

Standley CJ, Adriko M, Alinaitwe M, Kazibwe F, Kabatereine NB, Stothard JR, 2009. Intestinal schistosomiasis and soiltransmitted helminthiasis in Ugandan schoolchildren: a rapid mapping assessment. Geospat Health 4, 39-53.

Stein KJ, Waterman M, Waldon JL, 2008. The effects of vegetation density and habitat disturbance on the spatial distribution of ixodid ticks (Acari: Ixodidae). Geospat Health 2, 241-252. Steinmann P, Zhou XN, Matthys B, Li YL, Li HJ, Chen SR, 
Yang Z, Fan W, Jia TW, Vounatsou P, Utzinger J, 2007. Spatial risk profiling of Schistosoma japonicum in Eryuan county, Yunnan province, China. Geospat Health 2, 59-73.

Stensgaard AS, Jørgensen A, Kabatereine NB, Rahbek C, Kristensen TK, 2006. Modeling freshwater snail habitat suitability and areas of potential snail-borne disease transmission in Uganda. Geospat Health 1, 93-104.

Stensgaard AS, Saarnak CFL, Utzinger J, Vounatsou P, Simoonga C, Mushinge G, Rahbek C, Møhlenberg F, Kristensen TK, 2009. Virtual globes and geospatial health: the potential of new tools in the management and control of vector-borne diseases. Geospat Health 3, 127-141.

Stiles CW, 1939. Early history, in part esoteric, of the hookworm (uncinariasis) campaign in our southern United States. J Parasitol 25, 283-308.

Sturtz S, Ickstadt K, 2007. A descriptive and model-based spatial comparison of the standardised mortality ratio and the age-standardised mortality rate. Geospat Health 1, 255-266.

Suwannatrai A, Suwannatrai K, Haruay S, Piratae S, Thammasiri C, Khampoosa P, Kulsantiwong J, Prasopdee S, Tarbsripair P, Suwanwerakamtorn R, Sukchan S, Boonmars T, Malone JB, Kearney MT, Tesana S, 2011. Effect of soil surface salt on the density and distribution of the snail Bithynia siamensis goniomphalos in northeast Thailand. Geospat Health 5, 183-190.

Tanser FC, le Sueur D, 2002. The application of geographical information systems to important public health problems in Africa. Int J Health Geogr 1, 4.

Tellman N, Litt ER, Knapp C, Eagan A, Cheng J, Radonovich LJ, Jr., 2010. The effects of the Health Insurance Portability and Accountability Act privacy rule on influenza research using geographical information systems. Geospat Health 5, 3-9.

Theall KP, Scribner R, Ghosh-Dastidar B, Cohen D, Mason K, Simonsen N, 2009. Neighbourhood alcohol availability and gonorrhea rates: impact of social capital. Geospat Health 3, 241-255.

Tipayamongkholgul M, Lisakulruk S, 2011. Socio-geographical factors in vulnerability to dengue in Thai villages: a spatial regression analysis. Geospat Health 5, 191-198.

Tourre YM, Lacaux JP, Vignolles C, Ndione JA, Lafaye M, 2008. Mapping of zones potentially occupied by Aedes vexans and Culex poicilipes mosquitoes, the main vectors of Rift Valley fever in Senegal. Geospat Health 3, 69-79.

Troll C, 1939. Luftbildplan und ökologische Bodenforschung. Zeitschrift der Gesellschaft für Erdkunde zu Berlin 7/8, 241298.

UNDP, 2011. Human development report 2011. Sustainability and equity: a better future for all. United Nations Development Programme, New York, USA, 176 p.

Utzinger J, Raso G, Brooker S, de Savigny D, Tanner M, Ørnbjerg N, Singer BH, N'Goran EK, 2009. Schistosomiasis and neglected tropical diseases: towards integrated and sustainable control and a word of caution. Parasitology 136, 1859-1874.

Vignolles C, Lacaux JP, Tourre YM, Bigeard G, Ndione JA, Lafaye M, 2009. Rift Valley fever in a zone potentially occupied by Aedes vexans in Senegal: dynamics and risk mapping. Geospat Health 3, 211-220.

Vignolles C, Tourre YM, Mora O, Imanache L, Lafaye M, 2010. TerraSAR-X high-resolution radar remote sensing: an operational warning system for Rift Valley fever risk. Geospat Health 5, 23-31.

Wang XY, Hu WB, Tong S, 2009. Long-term exposure to gaseous air pollutants and cardio-respiratory mortality in Brisbane, Australia. Geospat Health 3, 257-263.

Watson M, 1921. The prevention of malaria in the Federated Malay States - a record of 20 years progress. John Murray, London, $381 \mathrm{p}$.

Watson M, 1953. African highway: the battle for health in Central Africa. John Murray, London, 283 p.

Wayant NM, Maldonado D, Arias AR, Cousiño B, Goodin DG, 2010. Correlation between normalized difference vegetation index and malaria in a subtropical rain forest undergoing rapid anthropogenic alteration. Geospat Health 4, 179-190.

Wen TH, Chen DR, Tsai MJ, 2010. Identifying geographical variations in poverty-obesity relationships: empirical evidence from Taiwan. Geospat Health 4, 257-265.

Widgren S, Frössling J, 2010. Spatio-temporal evaluation of cattle trade in Sweden: description of a grid network visualization technique. Geospat Health 5, 119-130.

Willgert KJE, Schroedle B, Schwermer H, 2011. Spatial analysis of bluetongue cases and vaccination of Swiss cattle in 2008 and 2009. Geospat Health 5, 227-237.

Williams RAJ, Xiao XM, Peterson AT, 2011. Continent-wide association of $\mathrm{H} 5 \mathrm{~N} 1$ outbreaks in wild and domestic birds in Europe. Geospat Health 5, 247-253.

Wu J, 2006. Cross-disciplinarity, landscape ecology, and sustainability science. Landsc Ecol 21, 1-4.

Wu XH, Wang XH, Utzinger J, Yang K, Kristensen TK, Berquist R, Zhao GM, Dang H, Zhou XN, 2007. Spatio-temporal correlation between human and bovine schistosomiasis in China: insight from three national sampling surveys. Geospat Health 2, 75-84.

Yang GJ, Gao Q, Zhou SS, Malone JB, McCarroll JC, Tanner M, Vounatsou P, Bergquist R, Utzinger J, Zhou XN, 2010. Mapping and predicting malaria transmission in the People's Republic of China, using integrated biology-driven and statistical models. Geospat Health 5, 11-22.

Yang GJ, Vounatsou P, Tanner M, Zhou XN, Utzinger J, 2006. Remote sensing for predicting potential habitats of Oncomelania hupensis in Hongze, Baima and Gaoyou lakes in Jiangsu province, China. Geospat Health 1, 85-92.

Yang GJ, Vounatsou P, Zhou XN, Utzinger J, Tanner M, 2005. 
A review of geographic information system and remote sensing with applications to the epidemiology and control of schistosomiasis in China. Acta Trop 96, 117-129.

Yiannakoulias N, Wilson S, Kariuki HC, Mwatha JK, Ouma JH, Muchiri E, Kimani G, Vennervald BJ, Dunne DW, 2010. Locating irregularly shaped clusters of infection intensity. Geospat Health 4, 191-200.

Yu QZ, Scribner R, Carlin B, Theall K, Simonsen N, GhoshDastidar B, Cohen D, Mason K, 2008. Multilevel spatio-temporal dual changepoint models for relating alcohol outlet destruction and changes in neighbourhood rates of assaultive violence. Geospat Health 2, 161-172.

Zendejas-Martínez H, Peterson AT, Milián-Suazo F, 2008. Coarse-scale spatial and ecological analysis of tuberculosis in cattle: an investigation in Jalisco, Mexico. Geospat Health 3, 29-38.

Zhen HL, Lawson AB, McDermott S, Lamichhane AP, Aelion $\mathrm{M}, 2008$. A spatial analysis of mental retardation of unknown cause and maternal residence during pregnancy. Geospat Health 2, 173-182.

Zhen HL, McDermott S, Lawson AB, Aelion CM, 2009. Are clusters of mental retardation correlated with clusters of developmental delay? Geospat Health 4, 17-26.

Zhou XN, Lv S, Yang GJ, Kristensen TK, Bergquist NR, Utzinger J, Malone JB, 2009. Spatial epidemiology in zoonotic parasitic diseases: insights gained at the $1^{\text {st }}$ International Symposium on Geospatial Health in Lijiang, China, 2007. Parasit Vectors 2, 10. 